\title{
"GREEN" COOPERATIVES IN THE FORMATION OF AN INSTITUTIONAL MECHANISM OF DEVELOPMENT OF ALTERNATIVE POWER ENGINEERING IN THE AGRARIAN SECTOR OF THE ECONOMY
}

\author{
Oleksandr Shpykuliak', Ilona Bilokinna²
}

\begin{abstract}
The essence of energy cooperatives and their value in a power system of the country is investigated in this article. The aim of this article is to investigate the role of "green" cooperatives in the institutional mechanism of alternative energy development in the agrarian sector of the Ukrainian economy. The object of the study is the green cooperatives of alternative energy in Ukraine. The subject of the study is green cooperatives and their role in the development of the alternative energy in Ukraine's agrarian sector. The methodology of this study is to use the institutional approach in the study of green energy cooperatives as an integral part of the institutional mechanism for the development of alternative energy in the agrarian sector. The basic concept "cooperation" and derivative "power cooperative" from the point of view of various authors are studied and our own explanation of the term "green power cooperative" is given. The condition of the development of alternative power engineering in Ukraine is investigated. Production and use of alternative energy sources in Ukraine have begun since 2007. In Ukraine, there operate 432 objects of the renewable power industry in Ukraine, to which the green tariff with a general power of $1534 \mathrm{MW}$ is established. The most energy consumed is biofuel and waste, while the second place is the consumption of hydropower and the third is the consumption of wind and solar energy. The agrarian sector of the Ukrainian economy has considerable potential for the development of renewable power as a rather developed branch of poultry farming and livestock production is favourable for the development of bioenergetics. Researches have shown that at this stage of development, it is possible to construct 1425 biogas installations on livestock and poultry-farming farms. For the last few years, there is an active construction of solar power stations. The biggest number of solar power stations is in the Kyiv, Dnipropetrovsk, and Ternopil regions. In this article, the institutional mechanism for the development of alternative power engineering is investigated. The main normative legal acts known as formal institutes which regulate renewable power in the country, namely laws, orders, strategy are considered. Such elements of the institutional mechanism as the organizations controlling and structuring the development of alternative energy sources, including the agrarian sphere of the national economy are analysed. The need for creation of green power cooperatives is proved and also an example of the successful experience of foreign countries in green power cooperation, namely such countries as Great Britain and Germany, is given. In Ukraine, such a form of the organization of activity as green power cooperation only begins to develop. In difficult economic and ecological conditions and conditions of the volatility of creation of green power cooperatives, it will allow solving a number of problems which are present now, including in the agrarian sector. However, there are barriers of institutional character which don't allow the population to create power cooperatives fully. In this case, only the state due to the creation of the effective institutional mechanism can help solve a difficult situation. Besides, there is a need for simplifying the process of creation of green power cooperatives and releasing from the statement of a lot of tariffs. Increase in the number of green power cooperatives in the agrarian sphere is a basis for overcoming volatility of the population in rural areas, increases in their profitability and reduction of expenses. Conclusions. Green cooperatives play a major role in shaping the institutional mechanism of alternative energy development in the agrarian sector of the Ukrainian
\end{abstract}

\footnotetext{
Corresponding author:

${ }^{1}$ Vinnytsia National Agrarian University, Ukraine.

National Scientific Center "Institute of Agrarian Economics", Ukraine.

E-mail:shpykuliak@ukr.net

ORCID: http://orcid.org/0000-0001-5257-5517

${ }^{2}$ Vinnytsia National Agrarian University, Ukraine.

E-mail: i.bilokinna@gmail.com

ORCID: http://orcid.org/0000-0001-5816-1067
} 
economy. Because rural people are only able to ensure their energy independence through the creation of green cooperatives, reduce the cost of purchasing energy resources, and also earn money selling produced energy and fuel. This will help not only increase the production and use of alternative energy sources in the agricultural sector of the country but will also greatly affect the development of rural areas.

Key words: green energy cooperative, institutional mechanism, renewable energy sources, agrarian sector, institution.

\section{JEL Classification: 013, 017, Q19, Q20, Q42}

\section{Introduction}

Many Ukrainian communities now face the challenge of securely providing themselves with energy. The growth of prices for traditional energy sources, as well as the difficult social situation, makes the Ukrainian population unlike the usual ways to look for alternative energy resources. In addition, the energy resources of the monopolists are too expensive and of poor quality. In addition, in foreign countries, there is a tendency towards a more distributed production of energy, when more and more energy is produced near its place of consumption, including energy consumers themselves. World practice shows that this tendency is quite beneficial for the Ukrainian population.

The urgency of the research topic is that it is a dream of every Ukrainian entrepreneur, and especially agrarian, that they have their own energy infrastructure and do not depend on the state and power generating monopolists, besides the Ukrainian agrarian sector is quite energy intensive. It is expensive to switch to alternative energy sources or to implement energy efficiency measures; therefore, it is necessary to pay attention to such a form of cooperation as green energy cooperatives.

The purpose of this article is to investigate the role of green energy cooperatives in the institutional mechanism of alternative energy development in the agricultural sector of Ukraine. According to the research goal, the following tasks must be performed:

- to define the essence of the concept of green energy cooperatives;

- to study the state of development of alternative energy in the agrarian sector of Ukraine;

- identify the most promising alternative energy sources for Ukraine;

- investigate the institutional mechanism for the creation and operation of green energy cooperatives;

- to study the role of green energy cooperatives in the development of the alternative energy sector in the agrarian sector.

Ukraine ratified the Paris agreement (Paris, December 12, 2015) at the XXI Conference of the Parties of the United Nations Framework Convention on Climate Change in 2016, which will come into force after 2020 upon termination of Kyoto Protocol, defining its future direction of development ecologically safe. Thus, it has confirmed the transition from exhaustible to renewable natural resources.
There is a constant informal organization in Ukraine that the monopolist who often abuses the situation can only be the producer and the supplier of energy. It is difficult for the population to realize that at this stage of development, each citizen, farmer, any subject of managing can become the producer of energy for their own consumption and not only their own. Selforganization of the population will help to break down this stereotype and solve a number of problems

In many developed countries (for example, Germany, Austria, the USA, etc.) the number of such producers of energy as power cooperatives increases quickly. They occupy a considerable share in the power balance of these countries.

In the institutional mechanism of alternative energy development in the agrarian sector, green energy cooperatives play a role which will be defined in the course of this study.

\section{What are the green power cooperatives?}

At the beginning of this century, a concept of ecologically safe and socially fair economic growth providing stage-by-stage formation of a new type of economy, that in foreign and, for quite some time now, in domestic practice is known under the name "green economy" becomes popular. This direction of ecologically balanced development is followed by growth of a share of investments in ecologically safe and energy saving technologies (Khodakivska, Shpykuliak, Suprun, 2017). The concept of green economy aims at economic transformation to foster improvement of social welfare and justice, at the same time, considerably reducing environmental threats and ecological deficiencies (Kasztelan, 2017). Alternative power engineering is one of the bases of functioning bases of "green economy," including the agrarian sector. And green power cooperatives are an important element of the development of alternative power engineering.

Exploring the category of green energy cooperatives, it is first necessary to study its main component, namely, what is meant by the word "cooperation." According to M. Tugan-Baranovsky, "cooperation should be recognized by an organization with certain class features" (Tugan-Baranovsky, Bulochnikov, Sorvina, Subbotina, 1989). Another modern scientist believes that cooperation leads to the emergence of 
a new productive force that far exceeds the productivity of its separate components (Gorbonos, Pavlonchik, 2013). In our opinion, this is the main characteristic of cooperation, that is, when there is an association of citizens with a common goal, they become stronger and more likely to achieve the goal than each of them alone.

The phenomenon of energy cooperatives is a new and young model in Ukraine, through which citizens are looking for ways to optimize their energy expenses and/ or generate revenue in the field of energy production. That is, energy cooperatives are an association of people for the benefit of the consumption and production of electricity (Aliyeva, Zhitnikovskaya, Brill, 2017).

Energy cooperatives (German - Energiegenossenschaften) are associations of citizens, enterprises, and organizations whose goal is, as a rule, the implementation of various local projects in the field of renewable energy. Often, such associations focus their efforts on decentralized, environmentally friendly and energy-independent companies and concerns. They are a form of so-called public participation/activity (German - Bürgerbeteiligung), i.e. citizens' participation in certain political processes and policy decisions, mainly at the regional and communal levels (Financial And Economic Analysis Office In The VRU, 2016).

We agree that "... cooperation in market conditions, including in rural areas, can only take place due to the commonality of the individual economic interests of individuals, which are realized through the mechanism of market self-organization, including the merger of their private property, that in society there are necessary institutional conditions - corresponding statutory support and rules of customary law" (Borschevsky, Kulish, Tsimbalist, Kravtsev, 2017).

In our opinion, green energy cooperatives are associations of citizens and other economic entities for the purpose of manufacturing, consuming, and selling environmentally friendly energy from renewable sources. For Ukraine, the creation of green energy cooperatives in the agrarian sector of the economy is a rather promising idea. Since a significant part of the Ukrainian economy is occupied by the agrarian sector, which needs cheap ecologically safe energy resources.

Good cooperative support is important for proper institutional provision, that is, appropriate formal institutions and initiated, equally important, informal institutions should be created at the state level. That is, there are a number of informal institutions that promote cooperation, including the creation of green energy cooperatives, "...the main informal institutions connected with the processes of cooperation should include: traditions of self-organization of the population, the culture of entrepreneurship, social capital, legal awareness, individual responsibility, self-education and self-development, social communication, moral norms and spiritual values, etc." (Borschevsky, Kulish, Tsimbalist, Kravtsev, 2017).

\section{The current state of development of alternative energy in Ukraine}

In pursuance of the October 2012 Decision of the Council of Ministers of the Energy Community D/2012/04/MC-EnC "On the Implementation of the Directive 2009/28/EC on the promotion of energy from renewable sources," which amends Further Directives 2001/77/EC and 2003/30/EC are being repealed, Ukraine has committed to bring the energy produced from renewable energy sources in the overall energy consumption structure to $11 \%$ by 2020 (Scientific And Project Center For The Development of The Unioned Energy Systems of Ukraine, 2016).

In recent years, Ukraine has made a significant step towards increasing the share of production and consumption of energy from renewable sources. Visually energy-based renewable energy sources can be seen in Figure 1.

In recent years, energy consumption from renewable sources has the largest volumes of biofuel and waste

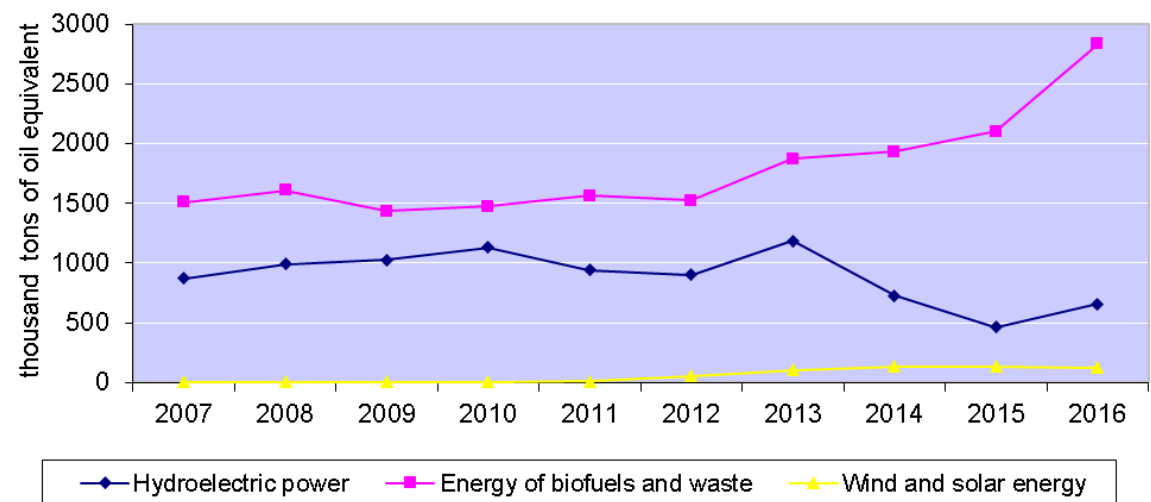

Figure 1. Renewable Energy Consumption for 2007-2016*

*2014-2016 without taking into account the temporarily occupied territory of the Autonomous Republic of Crimea and the city of Sevastopol and part of the ATO zone

Source: http://www.ukrstat.gov.ua/ 
energy consumption and in 2016 it has reached almost 3000 tons of oil equivalent. A steady increase occurs in the consumption of wind and solar power, and the consumption of hydropower in 2015 reached the lowest level since 2007, although in the next 2016 there was an increase.

The analysis of statistical data for livestock and poultry enterprises in Ukraine shows that at least 370 biogas plants (total capacity of $27 \mathrm{MW}$ ) can be built on pig farms in the power range of 30-190 kW, on farms with a capacity range up to $300 \mathrm{~kW}-965$ of these plants (in general at $75 \mathrm{MW}$ ) and 90 more (with a total capacity of $5 \mathrm{MW}$ ) in poultry farms - in the range of power $15-110 \mathrm{~kW}$ (Ukrainian farms show interest in biogas plants, 2017).

In an analytical report by the International Finance Corporation, it has been estimated that even with the use of 20 million tons of waste for energy production, Ukraine will cover $25 \%$ of annual electricity demand, which will allow over 8 billion cubic meters of natural gas to be replaced. That is, the use of only agricultural residues in full gives the opportunity to refuse to import natural gas by 75-80\% ("Green" reserve - annual results of alternative energy in the agro-industrial complex and plans for 2018, 2018).

The main instrument in Ukraine, with the help of which the state encourages business entities to produce energy from renewable sources, is the "green" tariff, which is one of the highest in Europe. As of the end of the 1st quarter of 2018, 432 renewable energy companies operate in Ukraine, which have a green tariff, with a total capacity of $1534 \mathrm{MW}$, of which:

- 235 SES with a total capacity of $841 \mathrm{MW}$;

- 24 wind power plants with a total capacity of $512 \mathrm{MW}$; - 138 MPS with a total capacity of 96 MW;

- 7 biomass power plants with a total capacity of $44 \mathrm{MW}$; - 28 biomass power plants with a total capacity of 41 MW (State Agency on Energy Efficiency and Energy Saving of Ukraine, 2018) (Figure 2).
As Figure 2 shows, such a type of renewable energy as solar has been actively developing in recent years since it is fast moving compared to others and with the highest green tariff (15-euro cents per $\mathrm{kWh}$ ). The tendency to increase the number of solar power stations not only among large and medium business entities but also small, private households is quite important. In Ukraine, the number of solar power stations in private households increased significantly during the first quarter of 2018 (Figure 3). This tendency is especially important for the agrarian sector, that is, for those who are in rural areas, they have difficulty with power supply and therefore, setting up the SES with the capacity up to $30 \mathrm{MW}$ has the opportunity to become non-volatile.

The largest number of solar power plants is in the Kyiv (517), Dnipropetrovsk (362), and Ternopil (261) regions. However, the most active construction of solar power plants in the first three months of 2018 took place in the Kirovohrad region, the number of facilities built during this period was 67 . This indicates that the favourable institutional environment for the development of solar energy is gradually being created.

Thus, in comparison with other countries, the development of alternative energy in Ukraine is at an initial stage. However, we already see some positive results, and the performance is improving every year.

\section{The role of green energy cooperatives in the development of alternative energy}

At this stage of development, Ukraine remains energy dependent on imports of energy resources. The situation can only be remedied by increasing the production of alternative energy sources, as the country's potential allows the development of all types of renewable energy. It is only necessary to create the right institutional mechanism that would push the citizens not only to realize the call parties of the consumption of alternative energy but also to personal production of energy from renewable sources.

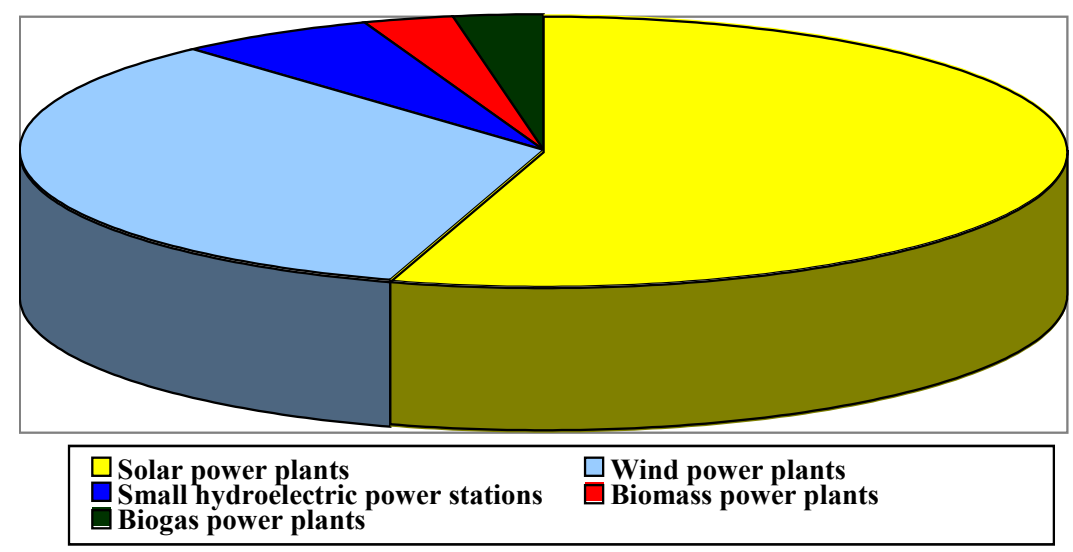

Figure 2. Power of renewable energy objects as of 31.03.2018

Source: Formed by the author on the basis of (State Agency on Energy Efficiency and Energy Saving of Ukraine, 2018 


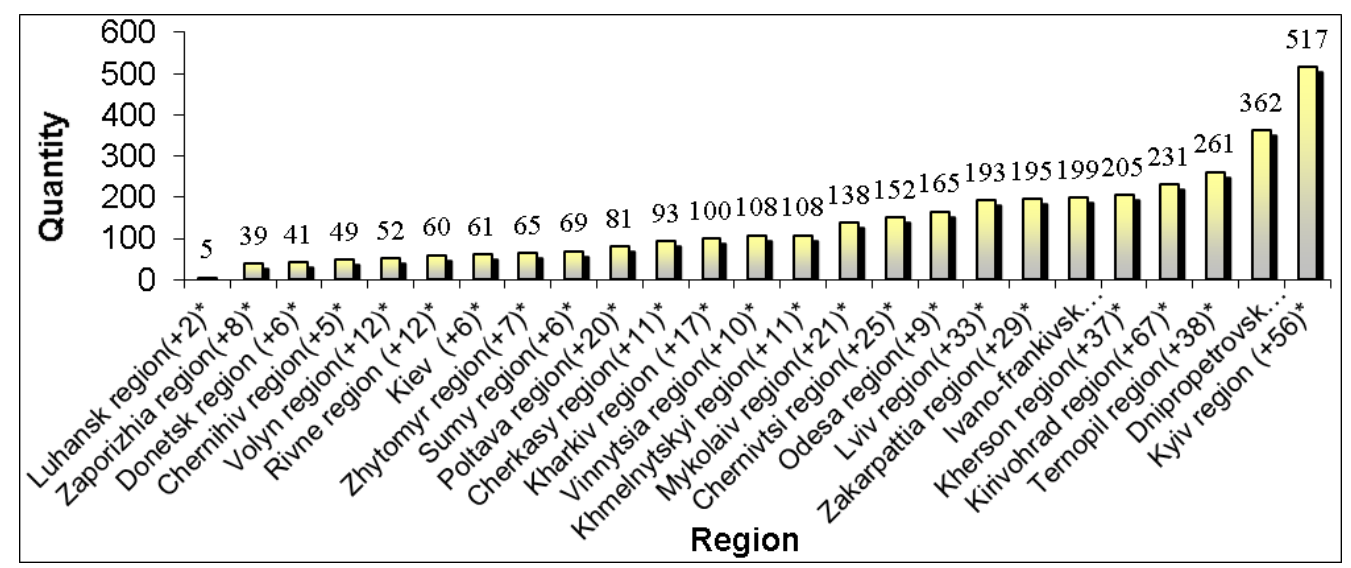

Figure 3. Number of solar power plants of private households as of 31.03.2018

* $(+\mathrm{x})$ - installed in Q1 2018

Source: "Green" reserve - annual results of alternative energy in the agro-industrial complex and plans for 2018, 2018

As already mentioned, the use and production of renewable energy sources are of great importance for our country, including the agrarian sector. A number of formal institutions for the development of alternative energy have been established in Ukraine, namely, the Law of Ukraine "On Alternative Fuels", the Law of Ukraine "On Alternative Energy Sources", the Law of Ukraine "On Combined Production of Thermal and Electric Energy (Cogeneration) and Utilization of Waste Energy Potentials", the Law of Ukraine "On Amending Certain Laws of Ukraine Regarding the Promotion of the Production and Use of Biological Fuels", the Decree of the Cabinet of Ministers of Ukraine dated 01.10.14 № 902-p "On the National Action Plan for Renewable Energy for the period up to 2020", the Energy Strategy of Ukraine for the period up to 2030, etc.

Europeans have already understood the need to move to clean energy sources and increase the pace, actively using the cooperative form of organization of activities. Therefore, in the UK, there are about 5 thousand cooperatives, mainly involved in solar and wind generation.

In Germany, energy cooperatives have now become rivals of energy holdings, generating up to $30 \%$ of renewable energy. Therefore, the Clean Energy for All Europeans Energy Package in the EU already limits the preferences for the primary connection of energy cooperatives to the network (Energy cooperatives, 2018).

In Ukraine, this form of organization of activities is only beginning to develop. In complex economic and ecological conditions and conditions of energy dependence, the creation of green energy cooperatives will solve a number of problems that are currently present, including in the agricultural sector. However, there are barriers of an institutional nature that prevent the population from the free creation of energy cooperatives.

Under the current legislation, a cooperative engaged in both the production and supply of energy for its members must obtain three licenses and approve three tariffs - for the production, transportation, and supply of electricity, and must abide by the conditions imposed on natural monopolies. It makes the organization of the cooperative more expensive and makes it dependent on local self-government (Energy cooperatives will promote the development of green energy and the solution of systemic problems, 2018). The process of creating green energy cooperatives needs to be simplified and exempted from the approval of many tariffs. But, unfortunately, in Ukraine, there is currently no legally established institution that would change this situation and promote energy cooperation in the agrarian sector.

The institutional mechanism for the development of alternative energy in the agrarian sector of Ukraine includes an effectively interconnected work of state and local authorities and public organizations that play a major role in creating the necessary regulatory and legal framework and, in the future, in creating the appropriate informal institutions. The state authorities that control the development of renewable energy, including in the agrarian sector, consist of: the Ministry of Energy and Coal Industry, State Agency on Energy Efficiency and Energy Saving of Ukraine, the National Agency for the Efficient Use of Energy Resources, the State Inspection on the Operation of Electric Power Plants and Networks, State Committee of Ukraine on Energy Saving, etc. Public organizations that fulfil the role of self-regulatory alternative energy organizations to a certain extent are the Agency for Renewable Energy, the Association of Alternative Fuel and Energy Market Participants in Ukraine, the Bioenergy Association of Ukraine, the Public Organization "Econovation", the Ukrainian Association for Renewable Energy, etc.

In the institutional mechanism of alternative energy development, including in the agrarian sector, one of the main roles of green energy cooperatives can be mentioned. Ukrainian peasant feels a significant lack 
of energy resources, which are quite expensive. It is possible to reduce energy dependence and energy and fuel costs by using renewable energy sources, as well as independently producing them. However, the cost of technology and equipment for installing a solar power plant on the roof of a building or the installation of a biogas plant based on agricultural waste is high and a separate peasant cannot afford to buy such. Therefore, it is advantageous for a Ukrainian peasant to join green energy cooperatives and to personally produce energy and fuel from alternative sources for the lighting of warehouses, for the operation of their cars, tractors, combines, for personal consumption, etc.

In the green energy cooperatives, as several peasants, so the whole rural community can be united. It is positive that the peasants will be able not only to provide themselves with energy and fuel but also to sell and earn from it. As a result, if the peasants see the financial benefits of green energy cooperation, they will actively join forces for energy independence, reducing their costs and increasing profits. The result will be an increase in the use of alternative energy sources in the agricultural sector, that is, green energy cooperatives are a new element of the institutional mechanism for the development of alternative energy in the agrarian sector.

A sufficient institutional barrier to the formation of green energy cooperatives is the unwillingness of citizens to unite. However, as noted above, the main thing is to start and that the citizens see a real example of the economic benefits of energy cooperation. The first green energy cooperative in Ukraine was created in the Kharkiv region in 2016. The experts of the Institute for Sustainable Development asked twenty agricultural entrepreneurs to join a biofuel cooperative for their own needs, but eight of them refused. The organization received a UN grant for procurement of equipment (Money for environmental innovations: where is choose fees for "green" initiatives, 2017). A year after the creation of this energy cooperative, 20 tons of diesel fuel was produced, which was enough for the needs of the members of the cooperative, namely for harvesting and subsequent sowing. However, nowadays there is more than one energy cooperative. Another example of the green energy cooperative is two cooperatives in Losiatyn village, Kremenets district, Ternopil region. The initial purpose of their creation was to grow raspberries and strawberries. But later, the members of the cooperatives began to use stalks of raspberries, which were cut every autumn, as fuel for their homes. Thanks to funding from UNDP and the EU, Yahidnyi Krai Cooperative bought and launched a briquetting line (Peasants heat up their homes by briquettes from the waste of raspberry of own production in Ternopil region, 2018). Thus, raspberry stalks turn into fuel briquettes and save on the use of gas. Despite the imperfection of legislation that overly regulates the work of energy cooperatives, thousands of Ukrainian communities can repeat the experience of the
Losiatyn community and reduce heating costs (Peasants heat up their homes by briquettes from the waste of raspberry of own production in Ternopil region, 2018). This is another proof that the creation of green energy cooperatives will increase the share of renewable energy in the agricultural sector, will significantly reduce the cost of the rural population and make them energy independent.

\section{Conclusions}

Summarizing the above said, one can draw the following conclusions:

1. Alternative energy is one of the foundations for the functioning of the green economy, including in the agricultural sector. Green energy cooperatives are an important element in the development of alternative energy.

2. Examining the category of green energy cooperatives, it is first necessary to study its main component, namely, what is meant by the word "cooperation." There is a great deal of thought about the definition of "cooperation." However, the simplest and most understandable definition sounds like this, cooperation is an association of citizens with a common goal, which leads to an increase in their force and accelerates the goal achievement.

3. From the basic concept of "cooperation" it follows that green energy cooperatives are associations of citizens and other economic entities for the purpose of manufacturing, consumption, and sale of environmentally friendly energy from renewable sources.

4. Proper institutional provision is important for encouraging cooperation, that is, appropriate formal institutions should be subsequently formed, as well as informal institutions should be created at the state level.

5. In recent years, there has been a steady increase in the use of alternative energy sources in all sectors of the economy, but biofuels and wastes are the most used. This is evidenced by the fact that in 2016, the use of this kind of energy reached almost 3000 tons of oil equivalent.

6. The domestic agricultural sector has sufficient potential for the further development of bioenergy out of biomass and waste. Biogas plants can be built near livestock and poultry farms, which will eliminate a number of problems. Such installations will enable both farms and the nearest settlement heating, as well as all waste from this production, will be processed.

7. Ukraine has the highest green tariff throughout Europe. This is a factor in encouraging the production of alternative energy, as well as the creation of green energy cooperatives, especially among the rural population.

8. Solar power is at its fastest pace of development, and in the first three months of 2018, the most active construction of solar power plants was in the Kirovohrad region (67 objects). Quite often, green 
power cooperatives are created for the construction of solar power plants since this type of energy is relatively fast.

9. The institutional mechanism of alternative energy development in the agrarian sector of Ukraine includes effective work of state and local authorities, as well as public organizations. And now, this mechanism also includes green energy cooperatives, which greatly enhances the ability of ordinary people to produce and consume environmentally safe and cheap energy sources.

\section{References:}

Aliyeva, O., Zhitnikovskaya, Y., Brill, N. (2017). Renewable Energy in Ukraine (RES) is a reality, independence and investment in the future.

Borschevsky, V., Kulish, I., Tsimbalist, N., Kravtsev, I. (2017). Use of socio-economic potential of cooperation for the development of rural areas of Ukraine. The State Institution of Regional Research Institute names of M. I. Dolishniy of The National Academy of Ukrainian Sciences. Retrieved August 15, 2018, from: http://ird.gov.ua/ irdp/p20170201.pdf

Energy cooperatives (2018). Retrieved August 10, 2018, from: https://biz.nv.ua/ukr/experts/ignatyev_s/ energetichni-kooperativi-v-ukrajini-659172.html

Energy cooperatives will promote the development of green energy and the solution of systemic problems (2018). Retrieved August 10, 2018, from: http://uacrisis.org/ua/52987-energetichni-kooperativi

Financial and Economic Analysis Office in the VRU (2016). Energy Cooperative: The Experience of Germany and Austria. Retrieved August 10, 2018, from: https://feao.org.ua/wp-content/uploads/2017/02/FEAO_Energy_ cooperatives.pdf

Gorbonos, F. V., Pavlonchik, N. F. (2013). Restructuring the economic space of a rural territorial unit as a basis for the development of cooperation. Proceedings of the All-Ukrainian Scientific and Practical Conference April 4-6, 2013. Zhytomyr: Zhytomyr National Agroecological University.

"Green" reserve - annual results of alternative energy in the agro-industrial complex and plans for 2018 (2018). Retrieved August 06, 2018, from: https://agropolit.com/spetsproekty/396-zeleniy-rezerv--richni-pidsumkialternativnoyi-energetiki-v-apk-ta-plani-na-2018

Kasztelan, A. (2017). Green Growth, Green Economy and Sustainable Development: Terminological and Relational Discourse. Prague Economic Papers, 26(4), 487-499. doi: https://doi.org/10.18267/j.pep.626

Khodakivska, O. V., Shpykuliak, O. G., Suprun, O. M. (2017). Institutes of the "green economy" in ensuring the sustainable development of the agricultural sector: the theoretical dimension. Business Inform, 7, 13-18.

Money for environmental innovations: where is choose fees for "green" initiatives (2017). Retrieved August 16, 2018, from: www.umoloda.kiev.ua/number/3250/159/118668/

Peasants heat up their homes by briquettes from the waste of raspberry of own production in Ternopil region (2018). Retrieved August 16, 2018, from: https://agroreview.com/news/na-ternopilshchyni-selyany-opalyuyutsvoyi-domivky-bryketamy-z-vidhodiv-malyny-vlasnoho-vyrobnyctva

Scientific and Project Center for the Development of the Unioned Energy Systems of Ukraine (2016). Status and prospects of development of small hydropower, solar, wind and other sources of renewable energy of foreign countries and Ukraine. Retrieved August 22, 2018, from: https://ua.energy/wp-content/uploads/2018/01/ 4.-Stan-i-perspektyvy-rozvytku-PDE.pdf

Ukrainian farms show interest in biogas plants (2017). Retrieved August 16, 2018, from: http://biowatt.com.ua/ trends/ukrainskie-fermy-proyavlyayut-interes-k-biogazovym-ustanovkam/

State Agency on Energy Efficiency and Energy Saving of Ukraine (2018). Information on capacity and volumes of electricity production by renewable energy companies which have a "green" fare. Retrieved August 07, 2018, from: http://saee.gov.ua/sites/default/files/Information\%20RES\%20in\%20Ukraine\%20\%20Q1\%202018.pdf

Tugan-Baranovsky, M. I., Bulochnikova, L. A., Sorvina, G. N., Subbotina, T. P. (1989). The social basis of cooperation. Mykolayiv: Economy.

Verkhovna Rada of Ukraine (2016). Law of Ukraine "About ratification of the Paris Agreement". Retrieved from: http://zakon5.rada.gov.ua/laws/show/1469-19 